\title{
RESEARCH OF VALIDATION PARAMETERS OF THE SPECTROPHOTOMETRIC QUANTITATIVE DETERMINATION METHOD OF RIBOFLAVIN BY SPECIFIC ABSORBANCE
}

\author{
O.Yevtifieieva, K.Proskurina, K.Dynnyk \\ National University of Pharmacy \\ Key words: quantitative determination; spectrophotometry; validation; riboflavin
}

\begin{abstract}
The study of validation parameters of the quantitative determination method of riboflavin by specific absorbance and their assessment have been conducted in order to standardize procedures for analysis by the specific absorbance and the stage-by-stage control of correctness of the results obtained during the validation experiment. According to the requirements of the State Pharmacopoeia of Ukraine (SPhU) the qualification of the spectrophotometer has been performed. The control of the cells $\left(\delta_{\text {dif }} \leq 0.002\right)$, absorbance accuracy, absorbance convergence with removing the cells $\left(R S D_{0} 0.0007 \% \leq 0.25 \%\right)$, as well as the study of the limit of stray light (absorbance of the solution at the wavelength of $198 \mathrm{~nm}$ is $2.56 \geq 2.0$, which meets the requirements of SphU) have been carried out. Characteristics and acceptance criteria of the assay method for riboflavin such as the nominal concentration of the substance in solution by the method, the nominal absorbance and requirements for its minimum value, the maximum uncertainty of the analysis procedure have been theoretically calculated. The linearity parameter has been studied at 9 points. The linear dependence plot has been constructed in the normalized coordinates. The values of $b, s_{b}, a, s_{a}, R S D_{0}$ and $r$ calculated comply with the requirements to parameters of the linear dependence. When studying the parameter of accuracy the systematic error is $\delta=0.72 \%$, which meets $\delta \leq 1.00 \%$. According to the results of the convergence study the relative confidence interval $\Delta_{A s}=0.83 \%$ does not exceed the critical value for convergence of the results $\Delta_{A S}=0.96 \%$. The validation parameters of the method meet the requirements of the SPhU and are characterized by qualitative analytical indicators.
\end{abstract}

Riboflavin (Vitamin $\mathrm{B}_{2}$ ) plays an important part in the process of carbohydrate, protein and fat metabolism, it also has an important role in maintaining the normal visual function of the eye and in the synthesis of hemoglobin. The chemical structure of riboflavin (6,7-dimethyl-9-(D-1-ribitil)-isoalloxazine) allows to determine the substance quantitatively by the methods of spectrophotometry, photocolorimetry, fluorometry, alkalimetry.

The literature review has revealed the fact that today new methods for quality control of riboflavin have been developed using HPLC [1,9], electrophoretic extraction [5], voltammetry [6]. In pharmacopoeial analysis for the assay method for the substance of riboflavin the European Pharmacopoeia [8], the State Pharmacopoeia of Ukraine (SPhU) [3], the British Pharmacopoeia [7] propose to use the absorption spectrophotometry method by the specific absorbance value, while the United States Pharmacopoeia offers fluorometry by measuring of the fluorescence intensity at the wavelength of $530 \mathrm{~nm}$ [10]. According to the SPhU the quantitative determination of riboflavin as a substance is performed using the spectrophotometry method by the specific absorbance in the buffer solution at the wavelength of $444 \mathrm{~nm}$. The riboflavin content is calculated using the specific absorption value, which is equal to 328 .

The aim of our work is to study the validation parameters of the quantitative determination method of riboflavin using the spectrophotometry method by specific absorbance in order to standardize procedures for analysis by the specific absorbance and the stage-bystage control of correctness of the results obtained during the validation experiment.

\section{Experimental Part}

When conducting the research the substance of riboflavin manufactured by Hebei Guangji Pharmaceutical Co., Ltd, No. H201005030FM meeting the requirements of the SPhU was used.

The following analytical equipment was used: a "SPECORD 200" spectrophotometer, AV 204 S / AMETTLER TOLEDO analytical balance, a "Sartorius AG" $\mathrm{pH}$ meter. Reagents, measuring glassware of class A (first class) and excipients meeting the requirements of the $\mathrm{SPhU}$ were used for the work.

The assay method for riboflavin. The assay is performed in a weakened light. In a brown-glass $500.00 \mathrm{ml}$

volumetric flask place $65.0 \mathrm{mg}$ of the substance and suspend in $5 \mathrm{ml}$ of water $R$. After having wetted the substance completely add $5 \mathrm{ml}$ of dilute sodium hydroxide solution $R$ and mix. As soon as the dissolution is complete, add $100 \mathrm{ml}$ of water $R$ and $2.5 \mathrm{ml}$ of glacial acetic acid $R$ and dilute to $500.00 \mathrm{ml}$ with water $R$. Place $20.00 \mathrm{ml}$ of this solution in a $200.00 \mathrm{ml}$ brown-glass volumetric flask, add $3.5 \mathrm{ml}$ of $14 \mathrm{~g} / 1$ solution of sodium acetate $R$ and dilute to $200.00 \mathrm{ml}$ with water $R$. Measure the absorbance of the solution obtained at the absorption maximum at $444 \mathrm{~nm}$.

Calculate the content of riboflavin using the specific absorbance value, which is 328 . 
The research results of the absorbance accuracy

\begin{tabular}{|c|c|c|c|}
\hline Wavelength, $\mathrm{nm}$ & Absorbance $A^{*}$ & $\begin{array}{c}\text { Specific absorbance } \\
A_{1 c,}^{1 \%}\end{array}$ & $\begin{array}{c}\text { Maximum limits for } \\
A_{1 c \mu}^{1 \%}\end{array}$ \\
\hline 235 & 0.7206 & 124.89 & from 122.9 to 126.2 \\
\hline 257 & 0.8326 & 144.30 & from 142.8 to 146.2 \\
\hline 313 & 0.2806 & 48.64 & from 47.0 to 50.3 \\
\hline 350 & 0.6213 & 107.67 & from 105.6 to 109.0 \\
\hline 430 & 0.9285 & 15.90 & from 15.7 to 16.1 \\
\hline
\end{tabular}

* The values of the absorbance are average out of three measurements of the solution.

The compensation solution was prepared in the same way as the solution of the substance using all components except riboflavin.

The measurements were performed with $1-\mathrm{cm}$ cells at $(20 \pm 1)^{\circ} \mathrm{C}$. The statistical processing of the experimental data was carried out according to the Article of the $\mathrm{SPhU}$ "Statistical analysis of the chemical experiment" ${ }^{\mathrm{N}}$ [3].

\section{Results and Discussion}

The human factor, the conditions of equipment and premises, sample preparation, etc., impact on the quality of the results of the analysis. Qualification of equipment for pharmacopoeial analysis indicates that due to the equipment the correct results can be obtained when conducting the spectrophotometric analysis. Therefore, the qualification of a SPECORD 200 spectrophotometer according to the requirements of the $\mathrm{SPhU}$ has been carried out and the following parameters have been determined:

- control of cells (difference of absorbance of the compensation solution meets the requirements $\delta_{d i f} \leq 0.002$ );

- control of the absorbance accuracy. The values of the specific absorption obtained and its permissible limits for each wavelength are shown in Table 1. The research results confirm the absorbance accuracy;

- according to the results of the absorbance convergence control with removing the cells the relative standard deviation $(0.0007 \%)$ to the average value has been calculated. It is less than $0.25 \%$ meeting the requirements of the $\mathrm{SPhU}$ );

- while investigating the limit of stray light the absorbance of the solution under research is greatly increased at the wavelength between $220 \mathrm{~nm}$ and
$200 \mathrm{~nm}$, and it is 2.559 at the wavelength of $198 \mathrm{~nm}$, and it meets the requirements of the SPhU.

Before the experiment there were some preliminary theoretical calculations. The acceptance criteria of the assay method for riboflavin are shown in Table 2. The additional characteristics and the acceptance criteria for the stage-by-stage control of correctness of the results obtained during the validation experiment, namely the nominal concentration of the substance in solution according to the method, the nominal absorbance and the requirements for its minimum value, the maximum uncertainty of the analysis procedure are given in Table 3.

Table 3 shows that the value of the nominal absorbance $A_{\text {nom }}=0.420\left(A_{\text {nom }}=A_{1 \mathrm{~cm}}^{1 \%} \cdot C_{\text {nom }}\right)$ of riboflavin does not meet the requirements of the minimum nominal absorbance:

$A_{n o m} \geq \frac{2}{\max \Delta_{A s}}$, in our case:

$\min A_{\text {nom }} \geq \frac{2}{\max \Delta_{A s}}=\frac{2}{3}=0,67$.

The parameter of uncertainty of the specific absorbance $\max \delta_{A}=\sqrt{2} \cdot \frac{100 \cdot \Delta A}{A_{\text {ном }}}=\sqrt{2} \cdot \frac{100 \cdot 0.01}{0,420}=3,4 \%$

practically does not exceed the maximum total uncertainty of the analysis $\max \Delta_{\mathrm{As}}=3.00 \%$.

The prognosis of the total uncertainty of the analysis results. Requirements to uncertainty of the analysis results $\left(\Delta_{A s}, \%\right)$ expressed as one-sided confidence interval with probability of $95 \%$ based on the permissible limit of the substance content $(97.0 \%-103.0 \%)$ are $\Delta_{A s}$

Table 2

The acceptance criteria of the assay method for riboflavin by specific absorbance

\begin{tabular}{|c|c|c|c|c|c|c|}
\hline Name & $B, \%$ & $\max \Delta_{A s} \%$ & $\max \delta, \%$ & $R S D_{0} \%$ & $\min R_{c}^{2}$ & $\max a, \%$ \\
\hline Riboflavin & 3.00 & 3.00 & 0.96 & 1.12 & 0.99331 & 4.39 \\
\hline
\end{tabular}

Table 3

Additional characteristics and the acceptance criteria of the assay method for riboflavin by specific absorbance

\begin{tabular}{|c|c|c|c|c|c|c|c|}
\hline Name & $\begin{array}{c}\text { Permissible } \\
\text { limits, } \%\end{array}$ & $\lambda, \mathrm{nm}$ & $A_{1 \text { c }}^{1 \%}$ & $\begin{array}{c}C_{\text {nom }} \\
\mathrm{mg} / 100 \mathrm{ml}\end{array}$ & $\mathrm{A}_{\text {nom }}$ & $\min A_{\text {nom }}$ & $\max \delta_{A^{\prime}} \%$ \\
\hline Riboflavin & $97-103$ & 444 & 328 & 1.281 & 0.420 & 0.67 & 3.40 \\
\hline
\end{tabular}




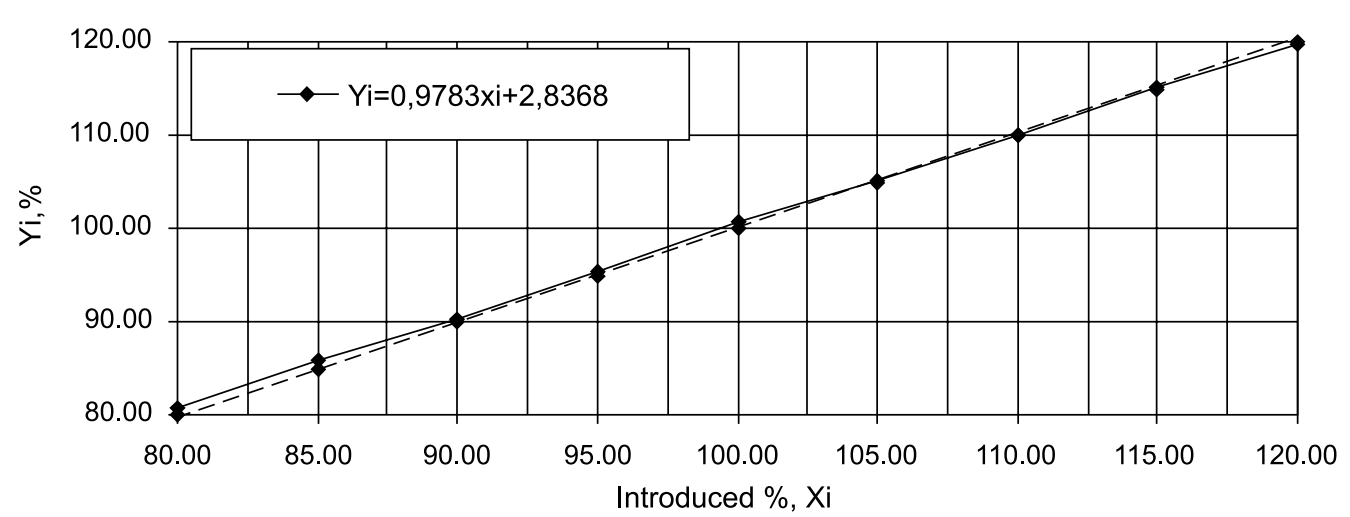

Fig. The plot of linear dependence of absorbance on the concentration of riboflavin in the normalized coordinates.

$(\%) \leq \max \Delta_{A s}(\%)=B=3 \%$. The total relative uncertainty of the analysis $\left(\Delta_{A s}, \%\right)$ in the case of the specific absorbance method is as follows [2]:

$$
\Delta_{A s}^{2}=\delta_{n o i c e}^{2}+\Delta_{F A O}^{2}+\Delta_{S P}^{2}+\delta^{2}{ }_{c a l} \leq \max \Delta_{A s}^{2}
$$

Requirements to the solvent. Water $R$ is used in determining riboflavin as a solvent. The optical density of the solvent is less than 0.2 measured against air at the wavelength of $444 \mathrm{~nm}$.

Specificity. The specificity test was performed to assess the uncertainty associated with the background absorption $\left(\delta_{\text {noise }}, \%\right)$ at the analytical wavelength in comparison with the maximum permissible uncertainty of the analysis $\max \Delta_{A s}$ :

$$
\begin{gathered}
\delta_{\text {exs }}=\frac{\sum_{i=1}^{k} A_{\operatorname{Im} p, i}}{A_{\text {nom }}} \cdot 100 \leq \max \delta= \\
=0,32 \cdot \max \Delta_{A s}=0,96 \% .
\end{gathered}
$$

Absorbance of the compensation solution $\left(\mathrm{A}_{\text {blank }}\right)$ was measured three times when removing the cell. It has been found that $\mathrm{A}_{\text {blank }}=0.03413, \mathrm{~A}_{\text {nom }}=0.420$. The contribution of the background absorption is

$\delta_{\text {exs }}=\frac{0,0011}{0,420} \cdot 100=0,26 \%$,

it does not exceed the maximum permissible uncertainty of the analysis.
Linearity. The study of linearity was performed at 9 points. The values used for calculations $\left(C_{\text {nom }}\right.$ and $\left.A_{\text {nom }}\right)$ (Table 3) were calculated by the formulas:

$$
\begin{gathered}
C_{\text {nom }}=\left[m_{\text {nom }} \cdot(100-L O D)\right] \cdot \text { Dil } \cdot\left(\text { Cont }_{\text {nom }} / 100\right), \\
A_{\text {nom }}=A_{1 \mathrm{~cm}}^{1 \%} \cdot C_{\text {nom }} .
\end{gathered}
$$

Due to the fact that the concentrations and analytical signals are advisable to give in the normalized coordinates the following values were calculated:

$$
\begin{gathered}
\mathrm{X}_{\mathrm{i}}(\%)=100 \cdot \mathrm{C}_{\mathrm{i}} / \mathrm{C}_{\text {nom }}, \mathrm{Y}_{\mathrm{i}}(\%)=100 \cdot \mathrm{A}_{\mathrm{i}} / \mathrm{A}_{\text {nom }}, \\
\mathrm{Z}_{\mathrm{i}}(\%)=100 \cdot \mathrm{Y}_{\mathrm{i}} / \mathrm{X}_{\mathrm{i}} \cdot
\end{gathered}
$$

The linear dependence of $\mathrm{Y}_{\mathrm{i}}$ from $\mathrm{X}_{\mathrm{i}}(Y=b \cdot X+a)$ shown in Fig. was plotted.

Calculations of parameters of the linear dependence were performed by the least square method. The calculated statistical values $b, s_{b}, a, s_{a}, R S D_{0}$ and $r$ are given in Table 4. The Table shows that the requirements for the parameters of the linear dependence are performed. The free member of the linear dependence $a$ slightly exceeds the criterion of practical uncertainty, so it can be neglected considering that the general requirements for acceptance are valid $(2.84 \% \leq 4.39 \%=\max a)$.

Accuracy and convergence. Table 5 shows that the

\begin{tabular}{|c|c|c|c|}
\hline Parameters & Value & Criteria (for permissible limits of $97-103 \%$, the number of points 9 ) & Conclusion \\
\hline$b$ & 0.9783 & - & - \\
\hline$s_{b}$ & 0.0057 & - & - \\
\hline \multirow{3}{*}{$a$} & \multirow{3}{*}{2.8368} & $\begin{array}{l}\text { statistical insignificance } \\
a \leq t(95 \%, g-2) \cdot s_{a}=1.89 \cdot s_{a}=1.89 \cdot 0.5774=1.09 \%\end{array}$ & unsatisfied \\
\hline & & $\begin{array}{l}\text { practical insignificance } \\
\left|a_{\delta A}\right| \leq \max \delta_{A}=0.71 \cdot \max \Delta_{A s}==0.71 \cdot 3=2.13 \%\end{array}$ & unsatisfied \\
\hline & & $\max a=4.39 \%$ & satisfied \\
\hline$s_{a}$ & 0.5774 & - & - \\
\hline$R S D_{0}$ & 0.2218 & $R S D_{0} \leq 1.12$ & satisfied \\
\hline$r$ & 1.0000 & $\min R_{c}^{2}=0.99331$ & satisfied \\
\hline
\end{tabular}
method is characterized by accuracy (the systematic error $\delta=0.72 \%$ meets the requirements of $\delta \leq 0.96 \%$ ), and by convergence (the relative confidence interval $\Delta_{A s}, \%=t(95 \%, 8) \cdot S z=1.8595 \cdot S z=0.83 \%$ does not

Table 4

Metrological characteristics of the linear dependence 
The results of analysis for test solutions and their statistical processing

\begin{tabular}{|c|c|c|c|c|}
\hline $\begin{array}{l}\text { No. of } \\
\text { the test } \\
\text { solution }\end{array}$ & $\begin{array}{l}\text { Introduced in } \% \\
\text { to the concentration } \\
\left(\mathrm{Xi}_{\text {actual }} \%\right)\end{array}$ & $\begin{array}{c}\text { Average optical } \\
\text { densities, } \mathrm{A} \\
\left(A_{1 \mathrm{~cm}}^{1 \%}=328, \lambda=444 \mathrm{~nm}\right)\end{array}$ & $\begin{array}{l}\text { Found in } \% \text { of the } \\
\text { nominal concentration } \\
\text { (Yi\%) }\end{array}$ & $\begin{array}{l}\text { Found in \% to introduced } \\
\qquad Z i=100 \cdot(Y i / X i)\end{array}$ \\
\hline 1 & 80.00 & 0.3455 & 81.03 & 101.28 \\
\hline 2 & 85.00 & 0.3676 & 86.20 & 101.48 \\
\hline 3 & 90.00 & 0.3864 & 90.63 & 100.70 \\
\hline 4 & 95.00 & 0.4079 & 95.67 & 100.70 \\
\hline 5 & 100.00 & 0.4307 & 101.02 & 101.02 \\
\hline 6 & 105.00 & 0.4497 & 105.47 & 100.45 \\
\hline 7 & 110.00 & 0.4709 & 110.44 & 100.40 \\
\hline 8 & 115.00 & 0.4927 & 115.56 & 100.48 \\
\hline 9 & 120.00 & 0.5118 & 120.03 & 100.02 \\
\hline & & & Mean, Z\% & 100.72 \\
\hline \multicolumn{4}{|c|}{ Relative standard deviation, $\mathrm{Sz} \%$} & 0.45 \\
\hline \multicolumn{4}{|c|}{ Relative confidence interval $\Delta_{A s^{\prime}} \%=t(95 \%, 8) \cdot S z=1.8595 \cdot S z$} & 0.83 \\
\hline \multicolumn{4}{|c|}{ Critical value for convergence of results $\Delta_{A s^{\prime}} \%=3.00 \cdot 0.32=0.96$} & 0.96 \\
\hline \multicolumn{4}{|c|}{ Systematic error $\delta$} & 0.72 \\
\hline \multicolumn{4}{|c|}{$\begin{array}{r}\text { Criterion of the systematic error insignificance 1) } \delta \leq \frac{\Delta_{A s}}{\sqrt{9}}=\frac{3}{3}=1 \\
\text { 2) if it is not satisfied 1), then } \delta \leq 3\end{array}$} & satisfied \\
\hline \multicolumn{4}{|c|}{ The overall conclusion of the method } & correct \\
\hline
\end{tabular}

The assessment of uncertainty of sample preparation of the assay method for riboflavin

\begin{tabular}{|l|c|c|}
\hline \multicolumn{1}{|c|}{ Operation of sample preparation } & Parameter & Uncertainty, $\%$ \\
\hline Weighing on the analytical balance, $\mathrm{g}$ & 65 & $0.2 / 65 \times 100=0.31$ \\
\hline Volumetric dilution, $\mathrm{ml}$ & 500.00 & 0.07 \\
\hline Taking an aliquot, $\mathrm{ml}$ & 20.00 & 0.21 \\
\hline Volumetric dilution, $\mathrm{ml}$ & 200.00 & 0.1 \\
\hline Uncertainty of sample preparation & $\Delta_{\mathrm{SP}}=\sqrt{0,31^{2}+0,07^{2}+0,21^{2}+0,1^{2}}=\sqrt{0,1537}=0,39 \%$ \\
\hline
\end{tabular}

exceed the critical value for convergence of the results $\left.\Delta_{A s}, \%=3.00 \cdot 0.32=0.96 \%\right)$.

The uncertainty of sample preparation of the method [4] (Table 6) has been assessed; it is insignificant compared to the maximum permissible uncertainty of the analysis results: $\Delta_{S p}=0.39 \% \leq 0.32 \cdot \max \Delta_{A s}=0.32 \cdot 3.0=$ $=0.96 \%$.

The total relative uncertainty of the analysis procedure was calculated using equation (1):

$$
\begin{gathered}
\Delta_{A s}=\sqrt{\Delta_{S P}^{2}+\Delta_{F A O}^{2}+\delta_{\text {noise }}^{2}+\delta_{A}^{2}}= \\
=\sqrt{0,39^{2}+0,49^{2}+0,025^{2}+3,4^{2}}=3,4 \geq 3,0 \% .
\end{gathered}
$$

The predicted total uncertainty of the analysis results of the assay method for riboflavin exceeds the maximum permissible uncertainty of the analysis procedure $\max \Delta_{A s}$.

\section{CONCLUSIONS}

The assessment of validation characteristics of the quantitative determination method of the riboflavin substance obtained experimentally by the specific absorbance allows us to conclude that the method is characterized by good reproducibility during control of the parameters of the spectrophotometer, cells difference, accuracy and convergence of absorbance even at the low value of the nominal absorbance.

\section{REFERENCES}

1. Гармонов С. Ю. // Хим.-фармач. журн. - 2011. - T. 45, №7. - С. 48-51.

2. Гризодуб А.И. Применение спектрофотометрии в контроле качества лекарственных средств // В кн.: «Аналитическое обеспечение создания, стандартизации и контроля качества лекарственных средств» / Под ред. чл.-кор. НАН Украины В.П.Георгиевского. - Х.: Изд-во «НТМТ», 2011. - Т. 1. - С. 92-202. 
3. Державна фармакопея України / Державне підприємство «Науково-експертний фармакопейний центр». 1-е вид. - Х.: РІРЕГ, 2001. - 556 с., Доп. 1. - Х.: РІРЕГ, 2004. - 520 с., Доп. 2. - Х.: РІРЕГ. - 2008. - 608 с.

4. Свтіфсєва О.А. // Укр. журн. клін. та лаб. мед. - 2012. - Т. 7, №3. - С. 229-235.

5. Коренман Я.И., Мокшина Н.Я., Зыков А.В. // ЖАХ. - 2012. - Т. 67, №12. - С. 1068-1071.

6. Bandžuchová L., Šelešovská R., Navrátil T., Chýlková J. et al. //Electrochimica Acta. - 2012. - Vol. 75. - P. 316-324.

7. British Pharmacopoeia [Електронний ресурс] / The British Pharmacopoeia Secretariat. - London, 2009. Vol. 1. - P. 10952. Режим достуny: http://www.vek-com.ru/78022.html.

8. European Pharmacopoeia. - 6-th ed. - Strasbourg : European Directorate for the Quality of Medicines, 2008. Vol. 2. -3308 p.

9. Pengfei Jin, Lufeng Xia, Zheng Li, Ning Che et al. // J. of Pharmac. and Biomed. Analysis. - 2012. - Vol. 70. P. $151-157$.

10. The USP Pharmacists' Pharmacopoeia. - 2-nd ed. - Rockville, 2008. - 1519 p.

\section{ДОСЛІДЖЕННЯ ВАЛІДАЦІЙНИХ ПАРАМЕТРІВ МЕТОДИКИ СПЕКТРОФОТОМЕТРИЧНОГО} КІЛЬКІСНОГО ВИЗНАЧЕННЯ РИБОФЛАВІНУ МЕТОДОМ ПОКАЗНИКА ПОГЛИНАННЯ О.А.Євтіфеєєва, К.І.Проскуріна, К.В.Динник

Ключові слова: кількісне визначення; спектрофоотометрія; валідація; рибофрлавін

3 метою стандартизації процедури проведення аналізу методом показника поглинання та поетапного контролю коректності отриманих результатів протягом експерименту проведено вивчення валідаційних параметрів методики кількісного визначення рибофрлавіну методом показника поглинання та зроблена їх оцінка. Відповідно до вимог Державної фрармакопеї України (ДФУ) проведено кваліфрікацію спектрофотометра. Здійснено контроль стану кювет ( $\delta_{\text {dif }} \leq$ 0.002), контроль правильності оптичної густини, перевірку збіжності оптичної густини з вийманням кювет $\left(R S D_{0} 0,0007 \% \leq 0,25 \%\right)$, контроль граничного рівня розсіяного світла (оптична густина розчину при довжині хвилі 198 нм склала 2,56 22,0), що відповідає вимогам ДФУ. Теоретично розраховані характеристики і критерії прийнятності методики кількісного визначення рибофлавіну: номінальна концентрація речовини у розчині за методикою, номінальна оптична густина та вимоги до їі мінімального значення, максимальна невизначеність методики аналізу. Вивчено параметр лінійності на 9 точках. Побудовано графрік лінійної залежності у нормалізованих координатах. Розраховані величини $b, s_{b}, a, s_{a}, R S D_{0}$ ma r відповідають вимогам до параметрів лінійної залежності. При дослідженні параметра правильності систематична похибка склала $\delta=0,72 \%$, що відповідає вимогам $\delta \leq 1,00 \%$. За результатами дослідження збіжності відносний довірчий інтервал $\Delta_{\text {as }}=0,83 \%$ не перевищує критичне значення для збіжності результатів $\Delta_{a s}=0,96 \%$. Валідаційні параметри методики відповідають критеріям прийнятності ДФУ та характеризуються якісними аналітичними показниками.

\section{ИССЛЕДОВАНИЕ ПАРАМЕТРОВ МЕТОДИКИ СПЕКТРОФОТОМЕТРИЧЕСКОГО КОЛИЧЕСТВЕННОГО ОПРЕДЕЛЕНИЯ РИБОФЛАВИНА МЕТОДОМ ПОКАЗАТЕЛЯ ПОГЛОЩЕНИЯ \\ О.А.Евтифеева, К.И.Проскурина, Е.В.Дынник}

Ключевые слова: количественное определение; спектрофотометрия; валидация; рибофрлавин

С целью стандартизации процедуры проведения анализа методом показателя поглощения и поэтапного контроля корректности полученных результатов во время эксперимента проведено изучение валидационных параметров методики количественного определения рибофрлавина методом показателя поглощения и дана их оценка. Согласно требованиям Государственной фрармакопеи Украины (ГФУ) проведено квалификацию спектрофотометра. Осуществлен контроль состояния кювет ( $\left.\delta_{\text {dif }} \leq 0.002\right)$, контроль правильности оптической плотности, проверку сходимости оптической плотности с извлечением кювет (RSD $0,0007 \% \leq 0,25 \%)$, проведены исследования предельного уровня рассеянного света - оптическая плотность резко увеличивалась при длине волны между 220 нм и 200 нм и составила 2,559 при длине волны 198 нм, что соответствует требованиям ГФУ. Теоретически рассчитаны характеристики и критерии приемлемости методики количественного определения рибофрлавина: номинальная концентрация вещества в растворе по методике, номинальная оптическая плотность и требования к ее минимальному значению, максимальная неопределенность методики анализа. Изучены параметр линейности на 9 точках. Построен график линейной зависимости в нормализованных координатах. Рассчитанные величины $b, s_{b}, a, s_{a}, R S D_{0} u r$ соответствуют требованиям к параметрам линейной зависимости. При исследовании параметра правильности систематическая погрешность составила $\delta=0,72 \%$, что соответствует требованиям $\delta \leq 1,00 \%$. По результатам исследования сходимости относительный доверительный интервал $\Delta_{A s}=0,83 \%$ не превышает критическое значение для сходимости результатов $\Delta_{A s}=0,96 \%$. Валидационные параметры методики соответствуют критериям приемлемости ГФУ и характеризуются качественными аналитическими показателями. 